\title{
PERANAN LESSON STUDY DALAM PROSES EVALUASI PENGAJAR
}

\author{
Ismail Sangkala \\ ismail@unismuh.ac.id
}

Mungkin kita pernah mendengar atau mungkin saja belum pernah mendengar istilah diatas; lesson study bukanlah sebuah metode ataupun strategy dalam mengajar. Menurut sejarahnya, lesson study pertama kali diperkenalkan oleh Negari sakura yaitu Negara Jepang. Penerapan lesson study diaplikasikan oleh Negara tersebut untuk mencapai dan melihat aktifitas pengajaran di sekolah atau lembaga pendidikan. Dalam hal ini, Fernadez dan Yoshida (2004:7) mengemukakan bahwa lesson study merupakan terjemahan langsung dari terminology bahasa Jepang "Jugyokenkyu" yang terdiri atas kata: "Jugyo" yang berarti pelajaran (lesson) dan "Kenkyu" berarti menyelidiki (study or research).

Dengan melihat terminology ini, maka dapat didefinisikan secara luas bahwa lesson study adalah mempelajari bagaimana pembelajaran berlangsung dalam kelas dan bertitik berat pada kelompok guru/dosen secara bersama mengevaluasi proses pembelajaran yang dilaksanakan oleh kelompok atau komunitas 
mereka sendiri. Adapun istilah dalam bahasa inggris adalah "Lesson that are the object of one's study". Sejalan dalam hal ini, Muchtar Karim (Universitas Negeri Malang) menyatakan bahwa lesson study bermaksud untuk meningkatkan keprofesionalan guru/dosen serta meningkatkan kualitas proses dan hasil pembelajaran.

Beberapa guru/dosen terkendala dalam mengevaluasi dan mengoreksi cara atau metode yang dibawakan kedalam proses pengajaran atau pembelajaran, hal ini disebabkan oleh penerapan guru/dosen yang terkadang masih mengacuhkan dan belum memikirkan untuk melakukan proses pengajaran secara bersama. Maksudnya adalah dengan melibatkan beberapa rekan guru/dosen untuk untuk mengoreksi atau mengobservasi tata cara pelaksanaan pengajaran di kelas. Kita pastinya telah menyadari bahwa mengoreksi diri sendiri terkadang kurang objektif dibanding ketika seorang tenaga pengajar (guru/dosen) meminta rekan mereka untuk melihat atau mengobservasi dalam pelaksanaannya. Sehingga guru/dosen dapat menemukan cara terbaik untuk menyampaikan berbagai konsep yang diajarkan kedepannya. 
Tahap yang dijalankan dalam lesson study terdiri atas 3 tahap, antara lain sebagai berikut:

1. Tahap Perencanaan (Plan)

Pada tahap ini, tim guru/dosen melakukan proses perencanaan yang matang dan tersistematis. Selanjutnya menyiapkan berbagai keperluan pada proses pelaksanaan kedepannya, seperti melengkapi perangkat pembelajaran/pengajaran, media pengajaran dan lain sebagainya.

2. Tahap Pelaksanaan (Do)

Tahap berikutnya adalah melaksanakan atau mengimplementasikan apa saja yang telah kita rencanakan secara matang. Pada proses ini, tentu saja ada yang menjadi guru/dosen model dan anggota tim lainnya menjadi pengamat (observer). Tahapan ini guru/dosen model menyampaikan konsep dan materi pengajaran seperti biasanya tanpa ada tekanan atau sikap ketidak percayaan diri dalam proses tersebut. Adapun para pengamat mencatat segala aktifitas yang dianggap kurang dan perlu untuk dikoreksi dan disampaikan kepada guru/dosen model setelah kelas selesai. 
Catatan tersebut bukan hanya aktifitas model tetapi aktifitas siswa juga.

\section{Tahap Evaluasi (See)}

Tahap terakhir adalah evaluasi, tahapan ini tim guru/dosen kembali berembug atau berdiskusi tentang data atau hasil rekaman yang didapatkan dari proses pengajaran guru/dosen model tersebut. Evaluasinya tentu saja membicarakan hal yang terbaik, dimanakah titik kelemahan dan kelebihan dari proses pengaplikasian proses pembelajaran.

Penulis bermaksud mengingatkan bahwa ketiga proses tersebut tidak hanya berakhir dalam 1 (satu) siklus saja, tetapi bisa jadi dilakukan dalam beberapa siklus jika diperlukan, hal ini sematamata untuk mendapatkan hasil yang super-duper maksimal dalam proses pengajaran kedepannya. Perlu diingat kembali bahwa lesson study bukanlah sebuah metode atau strategy dalam mengajar tetapi lesson study merangkum semua aspek yang terjadi dalam proses mengajar. 